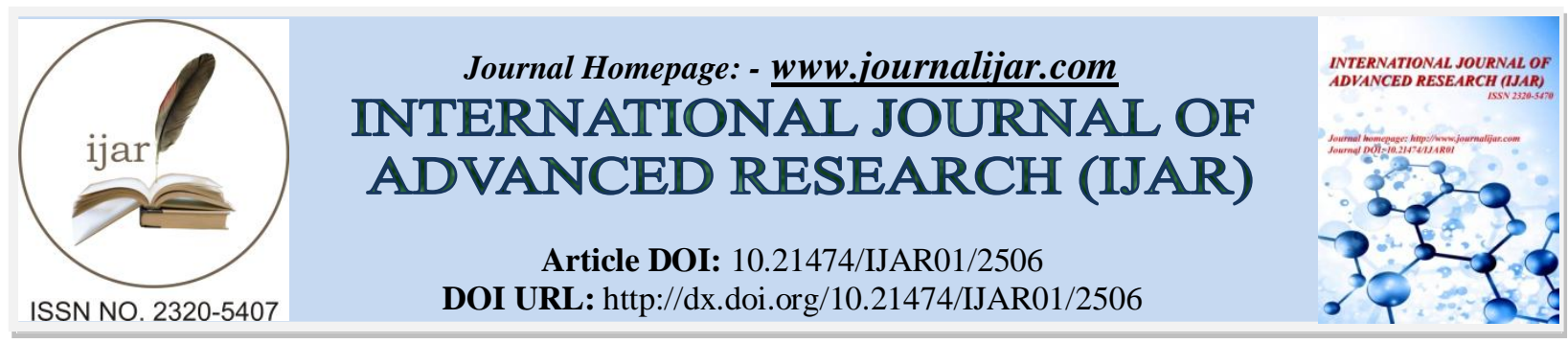

RESEARCH ARTICLE

\title{
FOLIC ACID AS A NUTRIENT SUPPLEMENT WITH MULBERRY LEAF AND ITS IMPACT ON THE ECONOMIC TRAITS OF SILKWORM (BOMBYX MORI L.).
}

\section{R. Ravi Kumara and M. N. Anil Kumar.}

Silkworm Physiology and Biochemistry Laboratory, DOS in Sericulture Science, University of Mysore, ManasaGangothri, Mysore-6, Karnataka, India.

\section{Manuscript Info}

Manuscript History

Received: 25 October 2016

Final Accepted: 23 November 2016

Published: December 2016

Key words:-

silkworm, folic acid, multivoltine

breeds, economic traits.

\section{Abstract}

The nutritive requirement in the silkworm, Bombyx mori L. arise like any other organism for growth, reproduction and quantity of silk production. Like any other heterotropic, the silkworm should obtain all the chemical substances in required quantity from its food material. An attempt has been made in the present investigation to record the effect of mulberry leaves supplemented with folic acid at different concentrations viz., 02, 04, and $06 \%$ on the economic traits in multivoltine silkworm breeds namely MU-1 and Hosa Mysore. The result of the study revealed that, the expression for economic traits viz., mature larval weight, cocoon weight, shell weight, shell ratio, filament length, filament weight, denier, renditta, and fecundity were maximum in both the breeds at $6 \%$ concentration over control batch.

Copy Right, IJAR, 2016,. All rights reserved.

\section{Introduction:-}

The silkworm, Bombyx mori L. is monophagous insect and consumes only mulberry leaves during larval stage of its life cycle. The mulberry silk contributes over $76 \%$ of raw silk produced by sercigenous insects in the country. The quality of mulberry leaves is of utmost importance for production of good quality of cocoons. The performance of silkworm such as growth, reproductive potentiality and quantum and quality of cocoon production depends on nutrient composition of food, which includes both absolute and relative amounts of proteins, amino acids, lipids, carbohydrates, sterols, water, minerals, vitamins, etc., besides its genetic endowment. The silkworm requires several vitamins for their growth and survival.

The vitamin is referred as an accessory indispensable food factor, organic in nature, required by an organism in small amount to maintain normal growth and regulation of metabolism. Generally, vitamins are synthesized by plant and are found in animals as a result of food intake or the activity of the microorganism in the gut. Some vitamins become part of the enzyme system, which is actively, involved in the enzyme action. Lack of any vitamins in the diet of the young animals prevents growth. Vitamin deficiency disease in organisms can be cured or prevented by supplementation of the vitamin rich food.

\section{Materials and Methods:-}

The methods followed and materials used in the current study are presented under the following headings:

Corresponding Author:- R. Ravi kumara.

Address:- Silkworm Physiology and Biochemistry Laboratory, Dos in Sericulture Science, University of Mysore, Manasa-Gangothri, Mysore-6, Karnataka, India. 


\section{Materials:-}

The multivoltine silkworm races namely Hosa Mysore and MU1 were taken for the present investigation

\section{Rearing and maintenance of silkworm larvae:-}

The selected silkworm races were reared by employing standard rearing techniques advocated by Dandin and Giridhar (2010).

\section{Supplementation of ascorbic acid:-}

Folic acid at varied concentrations viz., $0.2,0.4$ and $0.6 \%$ were sprayed on ventral surface of mulberry variety leaf and shade dried and fed to the silkworms. The treated leaves are fed to silkworm twice a day during fifth instar. The batch I $\left(\mathrm{T}_{1}\right)$ larvae received $0.2 \%$ folic acid sprayed mulberry leaves, the batch II $\left(\mathrm{T}_{2}\right)$ larvae received $0.4 \%$ folic acid sprayed mulberry leaves, the batch III $\left(\mathrm{T}_{3}\right)$ larvae received $0.6 \%$ folic acid sprayed mulberry leaves, the batch IV $\left(\mathrm{T}_{4}\right)$ larvae received mulberry leaves sprayed with distilled water (control) and batch $\mathrm{V}\left(\mathrm{T}_{5}\right)$ larvae were reared on natural diet (absolute control). In each treatment three replications were maintained.

\section{Observations recorded:-}

\section{Larval weight (g):-}

Ten larvae were randomly selected in each replication of every treatment and weighed just before spinning and average single larval weight was computed.

\section{Cocoon weight (g):-}

Ten cocoons were randomly selected from each treatment replication-wise, weighed individually and average single cocoon weight was computed.

\section{Pupal weight (g):-}

Weight of ten pupae from the cocoons already weighed will be recorded replication-wise in all the treatments and single pupal weight was computed.

\section{Shell weight (g):-}

After removing the pupa and larval exuvium from the cocoons, the individual shell weight was recorded.

\section{Shell ratio (\%);-}

The shell ratio was calculated using the formula:

Shell ratio $(\%)=\frac{\text { shell weight }(\mathrm{g})}{\text { Coccon weight }(\mathrm{g})} \times 100$

\section{Filament Length (m):-}

Ten cocoons were randomly selected from each batch was reeled to find out the single filament length of the cocoon using epprouvette and was determined by adopting the formula:

$\mathrm{L}=\mathrm{R} \times 1.125$

$\mathrm{R}=$ Number of revolutions recorded by an epprouvette.

$1.125=$ Circumference of epprouvette in meter.

\section{Filament Weight (g):-}

Ten cocoons were randomly selected from each batch was reeled and average filament weight was recorded.

\section{Denier:-}

This denotes the thickness of the filament, 9000 meters of the silk filament weighing $1 \mathrm{~g}$ is considered as 1 denier. It was calculated using following formula:

Denier $=\frac{\text { Weight of the filament }}{\text { Length of the filament }} \times 9000$

\section{Renditta:-}

This is a measure of actual silk available from the cocoons. The renditta was expressed as the quantity of green cocoons required to get a $\mathrm{kg}$ of raw silk.

Renditta $=\frac{\text { Weight of cocoons reeled }}{\text { Weight of raw silk obtained }}$ 


\section{Fecundity:-}

The character indicates the number of eggs laid by an individual moth. It is obtained by counting all the eggs in the laying.

\section{Analysis of data:-}

The data obtained on the fortified mulberry leaves with folic acid on the larval and cocoon parameters of the selected multivoltine races are analysed by adopting standard deviation $( \pm)$ method and mean values were expressed.

\section{Results:-}

Results of the investigation on the "folic acid and as a nutrient supplement with mulberry leaf and its impact on the economic traits of Bombyx mori L." are presented below (Table 1):

Table 1:- Influence of feeding silkworms with mulberry leaves supplemented with folic acid at varied concentration on larval and cocoon characters.

\begin{tabular}{|c|c|c|c|c|c|c|c|c|c|c|}
\hline Treatment & Race & $\begin{array}{l}\text { Larval } \\
\text { Weight( } \\
\text { g) }\end{array}$ & $\begin{array}{l}\text { Cocoo } \\
\text { n } \\
\text { weight } \\
\text { (g) } \\
\end{array}$ & $\begin{array}{l}\text { Shell } \\
\text { Weight } \\
\text { (g) }\end{array}$ & $\begin{array}{l}\text { Shell } \\
\text { Ratio } \\
\%\end{array}$ & $\begin{array}{l}\text { Filamen } \\
\text { t } \\
\text { Length( } \\
\text { m) } \\
\end{array}$ & $\begin{array}{l}\text { Filame } \\
\text { nt } \\
\text { weight( } \\
\text { w) } \\
\end{array}$ & $\begin{array}{c}\text { Deni } \\
\text { er }\end{array}$ & $\begin{array}{c}\text { Rendit } \\
\text { ta }\end{array}$ & $\begin{array}{c}\begin{array}{c}\text { Fecund } \\
\text { ity } \\
(\text { numbe } \\
\text { r) }\end{array} \\
\end{array}$ \\
\hline \multirow[t]{2}{*}{$0.2 \%$} & $\begin{array}{l}\text { Hosa } \\
\text { Myso } \\
\text { re }\end{array}$ & $\begin{array}{l}1.806 \\
\pm 0.024\end{array}$ & $\begin{array}{l}1.134 \\
\pm 0.008\end{array}$ & $\begin{array}{l}0.183 \\
\pm 0.009\end{array}$ & $\begin{array}{l}16.13 \\
\pm 0.73 \\
3\end{array}$ & $\begin{array}{l}465 \\
\pm 6.245\end{array}$ & $\begin{array}{l}0.113 \\
\pm 0.002\end{array}$ & $\begin{array}{c}2.18 \\
\pm 0.0 \\
53\end{array}$ & $\begin{array}{c}10.33 \\
\pm 0.086\end{array}$ & $\begin{array}{c}471 \\
\pm 4.509\end{array}$ \\
\hline & MU1 & $\begin{array}{l}1.673 \\
\pm 0.034\end{array}$ & $\begin{array}{l}1.062 \\
\pm 0.013\end{array}$ & $\begin{array}{l}0.162 \\
\pm 0.010\end{array}$ & $\begin{array}{l}15.25 \\
\pm 0.93 \\
6\end{array}$ & $\begin{array}{l}435 \\
\pm 4.163\end{array}$ & $\begin{array}{l}0.112 \\
\pm 0.003\end{array}$ & $\begin{array}{c}2.27 \\
\pm 0.1 \\
86\end{array}$ & $\begin{array}{c}10.16 \\
\pm 0.066\end{array}$ & $\begin{array}{c}454 \\
\pm 4.483\end{array}$ \\
\hline \multirow[t]{2}{*}{$0.4 \%$} & $\begin{array}{l}\text { Hosa } \\
\text { Myso } \\
\text { re }\end{array}$ & $\begin{array}{l}1.822 \\
\pm 0.050\end{array}$ & $\begin{array}{l}1.203 \\
\pm 0.002\end{array}$ & $\begin{array}{l}0.195 \\
\pm 0.003\end{array}$ & $\begin{array}{l}16.21 \\
\pm 0.20 \\
1\end{array}$ & $\begin{array}{l}473 \\
\pm 4.041\end{array}$ & $\begin{array}{l}0.121 \\
\pm 0.004\end{array}$ & $\begin{array}{c}2.28 \\
\pm 0.0 \\
76\end{array}$ & $\begin{array}{c}10.02 \\
\pm 0.633\end{array}$ & $\begin{array}{c}472 \\
\pm 4.58\end{array}$ \\
\hline & MU1 & $\begin{array}{l}1.771 \\
\pm 0.025\end{array}$ & $\begin{array}{l}1.098 \\
\pm 0.004\end{array}$ & $\begin{array}{l}0.170 \\
\pm 0.003\end{array}$ & $\begin{array}{l}15.48 \\
\pm 0.18 \\
1\end{array}$ & $\begin{array}{l}446 \\
\pm 7.211\end{array}$ & $\begin{array}{l}0.111 \\
\pm 0.009\end{array}$ & $\begin{array}{c}2.21 \\
\pm 0.1 \\
42\end{array}$ & $\begin{array}{c}9.98 \\
\pm 0.657\end{array}$ & $\begin{array}{c}464 \\
\pm 7.77\end{array}$ \\
\hline \multirow[t]{2}{*}{$0.6 \%$} & $\begin{array}{l}\text { Hosa } \\
\text { Myso } \\
\text { re }\end{array}$ & $\begin{array}{l}1.915 \\
\pm 0.026\end{array}$ & $\begin{array}{l}1.263 \\
\pm 0.001\end{array}$ & $\begin{array}{c}0.214 \\
\pm 0.014\end{array}$ & $\begin{array}{l}16.94 \\
\pm 1.06 \\
8\end{array}$ & $\begin{array}{l}510 \\
\pm 6.245\end{array}$ & $\begin{array}{l}0.133 \\
\pm 0.003\end{array}$ & $\begin{array}{c}2.34 \\
\pm 0.0 \\
71\end{array}$ & $\begin{array}{c}9.49 \\
\pm 0.251\end{array}$ & $\begin{array}{c}484 \\
\pm 2.082\end{array}$ \\
\hline & MU1 & $\begin{array}{l}1.854 \\
\pm 0.028\end{array}$ & $\begin{array}{l}1.208 \\
\pm 0.021\end{array}$ & $\begin{array}{l}0.202 \\
\pm 0.005\end{array}$ & $\begin{array}{l}16.72 \\
\pm 0.17 \\
6\end{array}$ & $\begin{array}{l}478 \\
\pm 6.429\end{array}$ & $\begin{array}{l}0.127 \\
\pm 0.002\end{array}$ & $\begin{array}{c}2.39 \\
\pm 0.0 \\
32\end{array}$ & $\begin{array}{c}9.51 \\
\pm 0.308\end{array}$ & $\begin{array}{c}477 \\
\pm 6.506\end{array}$ \\
\hline \multirow[t]{2}{*}{$\begin{array}{l}\text { Distilled } \\
\text { water }\end{array}$} & $\begin{array}{l}\text { Hosa } \\
\text { Myso } \\
\text { re }\end{array}$ & $\begin{array}{l}1.605 \\
\pm 0.042\end{array}$ & $\begin{array}{l}1.083 \\
\pm 0.010\end{array}$ & $\begin{array}{l}0.152 \\
\pm 0.004\end{array}$ & $\begin{array}{l}14.03 \\
\pm 0.25 \\
6\end{array}$ & $\begin{array}{l}428 \\
\pm 6.506\end{array}$ & $\begin{array}{l}0.093 \\
\pm 0.000\end{array}$ & $\begin{array}{c}1.95 \\
\pm 0.0 \\
16\end{array}$ & $\begin{array}{c}11.64 \\
\pm 0.142\end{array}$ & $\begin{array}{c}444 \\
\pm 3.786\end{array}$ \\
\hline & MU1 & $\begin{array}{l}1.542 \\
\pm 0.022\end{array}$ & $\begin{array}{l}0.883 \\
\pm 0.006\end{array}$ & $\begin{array}{l}0.130 \\
\pm 0.006\end{array}$ & $\begin{array}{l}14.72 \\
\pm 0.52 \\
5\end{array}$ & $\begin{array}{l}415 \\
\pm 4.122\end{array}$ & $\begin{array}{l}0.086 \\
\pm 0.006\end{array}$ & $\begin{array}{c}1.86 \\
\pm 0.1 \\
64\end{array}$ & $\begin{array}{c}10.86 \\
\pm 0.061\end{array}$ & $\begin{array}{c}440 \\
\pm 3.606\end{array}$ \\
\hline \multirow[t]{2}{*}{$\begin{array}{l}\text { Absolute } \\
\text { control }\end{array}$} & $\begin{array}{l}\text { Hosa } \\
\text { Myso } \\
\text { re }\end{array}$ & $\begin{array}{l}1.655 \\
\pm 0.009\end{array}$ & $\begin{array}{l}1.097 \\
\pm 0.007\end{array}$ & $\begin{array}{l}0.158 \\
\pm 0.002\end{array}$ & $\begin{array}{l}14.41 \\
\pm 0.11 \\
4\end{array}$ & $\begin{array}{l}434 \\
\pm 7.767\end{array}$ & $\begin{array}{l}0.095 \\
\pm 0.002\end{array}$ & $\begin{array}{c}1.97 \\
\pm 0.0 \\
34\end{array}$ & $\begin{array}{c}11.04 \\
\pm 0.089\end{array}$ & $\begin{array}{c}456 \\
\pm 3.512\end{array}$ \\
\hline & MU1 & $\begin{array}{l}1.574 \\
\pm 0.009\end{array}$ & $\begin{array}{l}0.895 \\
\pm 0.006\end{array}$ & $\begin{array}{l}0.13 \\
\pm 0.004\end{array}$ & $\begin{array}{l}14.97 \\
\pm 0.32 \\
6\end{array}$ & $\begin{array}{l}423 \\
\pm 4.790\end{array}$ & $\begin{array}{l}0.088 \\
\pm 0.003\end{array}$ & $\begin{array}{c}1.87 \\
\pm 0.0 \\
91\end{array}$ & $\begin{array}{c}10.37 \\
\pm 0.035\end{array}$ & $\begin{array}{c}450 \\
\pm 2.082\end{array}$ \\
\hline
\end{tabular}

Larval weight:-

Silkworms fed on mulberry leaves supplemented with folic acid expressed difference in respect of larval weight with maximum being in Hosa Mysore and MU1 at 0.6\% (1.915 and 1.854g). Followed by $0.4 \%$ (1.822 and 1.771g), respectively. While it was minimum at $0.2 \%$ in MU1 and Hosa Mysore (1.673 and $1.806 \mathrm{~g}$ ) when compared to control batches (1.542 and 1.605g), respectively. However, larvae fed on natural diet (absolute control) recorded larval weights of 1.655 and $1.574 \mathrm{~g}$ in Hosa Mysore and MU1. 


\section{Cocoon weight:-}

The breeds Hosa Mysore and MU1 expressed high cocoon weight on extra foliated mulberry leaves with folic acid at $0.6 \%(1.263$ and $1.208 \mathrm{~g})$ followed by $0.4 \%(1.203$ and $1.098 \mathrm{~g})$, respectively. As against to this, it was lowest at $0.2 \%$ in MU1 (1.062g) and Hosa Mysore (1.134g). However, larval fed on mulberry leaves sprayed with distilled water registered a cocoon weight of 1.083 and $0.883 \mathrm{~g}$ Hosa Mysore and MU1, respectively.

\section{Shell weight:-}

Shell weight in the indicator of shell yield and it is positively correlated with length of the shell filament. The larvae reared on mulberry leaves fortified with folic acid varied concentrations exhibit notable variation with respect to shell weight. The highest shell weight was observed on mulberry leaves supplement with folic acid at $0.6 \%$ in Hosa Mysore and MU1 (0.214 and 0.202g) followed by $0.4 \%$ (0.195 and $0.170 \mathrm{~g})$, respectively. While it was least at $0.2 \%$ in Hosa Mysore (0.162) and MU1 (0.183g). The minimum shell weight of 0.130 and $0.152 \mathrm{~g}$ were noticed in control batches of MU1 and Hosa Mysore, respectively.

\section{Shell ratio:-}

The breeds Hosa Mysore and MU1 fed on mulberry leaves fortified with folic acid at $0.6 \%$ registered maximum shell ratio (16.94 and $16.72 \%$ ) followed by $0.4 \%$ (16.21 and 15.48\%), respectively. On the other hand, it was lowest for said trait at $0.2 \%$ in MU1 (15.25\%) and Hosa Mysore (16.13\%) over control batches of MU1 (14.72\%) and Hosa Mysore (14.03\%), respectively.

\section{Filament length:-}

Filament length is one of the major contributing quantitative trait in silkworms. The silkworm reared on mulberry leaves supplemented with folic acid recorded marked differences in respect of filament length with maximum being in Hosa Mysore and MU1 at 0.6\% (510 and 478m) followed by $0.4 \%$ (443 and 446m), respectively. However, minimum filament length of 435 and $465 \mathrm{~m}$ were recorded at $0.2 \%$ in MU1 and Hosa Mysore when compared to control batches of MU1 (415m) and Hosa Mysore (428m), respectively.

\section{Filament weight:-}

The Breeds Hosa Mysore and MU1 expressed higher filament weight on fortified mulberry leaves with folic acid at $0.6 \%(0.133$ and $0.127 \mathrm{~g})$ followed by $0.4 \%(0.121$ and $0.111 \mathrm{~g})$, respectively. As against to this, it was longest at $0.2 \%$ in MU1 $(0.112 \mathrm{~g})$ and Hosa Mysore $(0.113 \mathrm{~g})$ where as control batches recorded filament weight of $0.086 \mathrm{~g}$ in MU1 and 0.093g in Hosa Mysore.

\section{Denier:-}

It denotes the size of the filament obtained from cocoons of silkworm breeds. Marginal variation was noticed with respect of denier among breeds provided with mulberry leaves fortified with folic acid at different concentration. The breeds Hosa Mysore and MU1 exhibited lowest denier at $0.2 \%$ (2.18 and 2.21d) and followed by $0.4 \%$ (2.28d). Similarly, highest denier was recorded at $0.6 \%$ in MU1 (2.39d) and Hosa Mysore (2.34d) over control batches of MU1 (0.086d) and Hosa Mysore (0.093d), respectively.

\section{Renditta:-}

This trait indicates as total silk available from the cocoon. Notable variations were noticed with respect to renditta among breeds provided with mulberry leaves fortified with folic acid at variance concentration. The breeds Hosa Mysore and MU1expressed lowest renditta at $0.6 \%$ (9.49 and 9.51) followed by $0.4 \%$ (10.02and 9.98), respectively. In contrast, highest renditta was observed at $0.2 \%$ in Hosa Mysore (10.33) and MU1 (10.16). Where as control batches recorded renditta of 10.86 and 11.64 in MU1 and Hosa Mysore, respectively.

\section{Fecundity:-}

The larvae reared on mulberry leaves fortified with folic acid exhibited marked variations in respect of fecundity with highest being in Hosa Mysore (484eggs) and MU1(477 eggs) at $0.6 \%$ concentration followed by $0.4 \%$ (472 and 464eggs), respectively. In contrast, it was lowest in MU1 (454 eggs) and Hosa Mysore (471 eggs) at 0.2\% concentration over control batches (440 and 444eggs), respectively.

\section{Discussion:-}

Vitamins are organic compounds required in trace amounts in the diet for proper growth and development. In general, plant synthesizes large amount of vitamins. A few animals and insects also synthesizes in lesser quantities. 
They resemble hormones in their function and both of them required because of their function as co-factor of enzymes and they are needed in little quantities corresponding to that of the appropriate catalytic activity. The specific dose requirement of different nutrients and vitamins suggests their specificity for various metabolic functions (Horie, 1980).

The folic acid (vitamin B9) is widely distributed in nature. It is found in many animals and plant tissues including micro organism. It plays a major role in cellular metabolism including the synthesis of some of the components of DNA and pigment precursor. It also involved in the catabolism of histidine. Yosuhiro and Sholchi (1971) mentioned that the silkworm growth decreased when folic acid was eliminated from artificial diet. Nirwani and Kaliwal (1996) determined that folic acid was phagostimulatory effects with significant increase in female and male cocoons weight and shell weight.

The results on the "Folic acid as a nutrient supplement with mulberry leaf and its impact on the economic traits of silkworm (Bombyx mori L.)" are discussed in the light of earlier workers and presented in the following paragraphs:

\section{Larval weight:-}

Silkworm breeds reared on fortified mulberry leaves with folic acid at different concentration exhibited notable influence on larval weight maximum being in Hosa Mysore (1.915 g) and MU1 (1.854 g) at $0.6 \%$ concentration over control batch. The increase in larval weight might be due to additional supplementation of folic acid along with mulberry leaves. The present finds was in conformity with the findings of Balasundaram et al. (2013) reported that the supplementation of $0.2 \%$ folic acid found to be optimum in which maximum larval weight noticed among different concentrations in bivoltine silkworm hybrid $\left(\mathrm{CSR}_{2} \mathrm{X} \mathrm{CSR}_{4}\right)$. Similar results were also observed with supplementation of folic acid, para-amino benzoic acid and combination of both in the silkworm larvae $\mathrm{NB}_{4} \mathrm{D}_{2}$ by Singaravelu et al. (2001)

\section{Cocoon weight:-}

Supplementation of folic acid at varied concentrations on silkworm breeds registered encouraging results on cocoon weight. The larvae reared on folic acid at $0.6 \%$ expressed higher cocoon weight of $1.263 \mathrm{~g}$ and $1.208 \mathrm{~g}$ in Hosa Mysore and MU1, respectively. The increase in cocoon weight in both breeds might be due to increase in absorption of folic acid by midgut epithelial cells followed by absorption by different body cells and transformation to cellular structure. These results are in agreement with those of EL-Karaksy and Idriss (1990) who noticed that silkworm hybrid (155 X 156) reared on mulberry leaf supplemented with folic acid at $2 \%$ recorded significantly higher cocoon weight over other concentrations as well as control batch. Similar results was also observed on some other vitamins by (Babu et al., 1992; Prasad et al., 1994; Nirwani and Kaliwal 1995; Singaravelu et al., 2001; Rai et al., 2002; Rahmathulla et al., 2007; Tantra and Kanika Trivedy 2011; Balasundaram et al., 2013) .

\section{Shell weight:-}

Silkworms nourished with mulberry fortified with folic acid at different concentrations registered notable influence on shell weight. The worms supplemented with folic acid at $0.6 \%$ exerted higher shell weight $(0.214 \mathrm{~g})$ in Hosa Mysore. On the other hand, MU1 recorded highest shell weight of $0.202 \mathrm{~g}$ over absolute control batch. The increase in shell weight might be due to additional supplementation of folic acid which enhances the biosynthesis of silkworm protein. These results corroborate the earlier findings of Balasundaram et al. (2013) who opined that supplementation of mulberry leaves with folic acid at the rate $0.2 \%$ enhance shell weight in the silkworm hybrid $\left(\mathrm{CSR}_{2} \mathrm{X} \mathrm{CSR}_{4}\right)$. Similar trend also noticed in some other vitamins by (Prasad et al., Nirwani and Kaliwal, 1995; Singaravelu et al., 2001; Rai et al., 2002; Rahmathulla et al., 2007; Tantra and Kanika Trivedy 2011) (Fig 4).

\section{Shell ratio:-}

Silkworms reared on mulberry leaves extra foliated with folic acid exerted marked influence on shell ratio. A concentration of folic acid at $0.6 \%$ resulted in higher shell ratio of 16.94 and $16.72 \%$ in Hosa Mysore and MU1, respectively when compared to control batch. Increase in the shell ratio might be due to enhanced silk productivity by additional supplementation of folic acid. These results are supported by the observations of Rahmathulla et al. (2007) who opined that the bivoltine hybrid $\left(\mathrm{CSR}_{2} \mathrm{X} \mathrm{CSR}\right.$ ) administrated with folic acid at concentration of 100 and $150 \mathrm{ppm}$ exhibit significantly higher shell ratio over other batches. Similarly administration of folic acid at 0.2 $\%$ concentration increases shell ratio in bivoltine hybrid ( $\left.\mathrm{CSR}_{2} \mathrm{X} \mathrm{CSR}_{4}\right)$ (Balasundaram et al., 2013). 


\section{Filament length:-}

Filament length has positive correlation with shell weight. The silkworm feed on mulberry leaf fortified with folic acid at varied concentration registered marked influence on filament length. The multivoltine breed Hosa Mysore and MU1 supplemented with folic acid at $0.6 \%$ exerted longer filament length 510 and $478 \mathrm{~m}$ over other concentrations and also silkworms provided with natural diet. The increase in filament length might be due to higher rate of silk protein synthesis by additional supplementation of folic acid. These results are in conformity in the finding of Rai et al. (2012) who reported that administration of folic acid through mulberry leaves facilitated nucleic acid synthesis in silk gland cells in turn improve the absolute silk content in the shell. Similar results are also reported in bivoltine hybrid $\left(\mathrm{CSR}_{2} \times \mathrm{CSR}_{4}\right)$ supplemented with folic acid with $0.2 \%$ over control batch (Balasundaram et al., 2013).

\section{Filament weight:-}

Silkworm breeds reared on fortified mulberry leaves with folic acid at varied concentration exhibited notable impact on filament weight. In the study, Hosa Mysore and MU1 expressed gain in the filament weight of 0.113 and $0.127 \mathrm{~g}$, respectively with folic acid supplementation at $0.6 \%$, respectively. The increase in filament weight in both the breeds might be due to higher rate of bio synthesis of silk protein by additional supplementation of folic acid. These results are agreement in the findings of Singaravelu et al. (2001) who observed that supplementation of mulberry leaves with combination of folic acid and para amino benzoic acid increase filament weight.

\section{Denier:-}

Silkworm nourished with mulberry leaves extra foliated with folic acid at lower concentration registered encouraging results, than the higher. The larvae reared on folic acid supplementation at $0.2 \%$ expressed lower denier of 2.18 in Hosa Mysore and 2.21 in MU1. These results are in conformity in the finding of Babu et al. (1992) who opined that fine denier was observed when the silkworm larvae provided with $1.5 \%$ folic acid.

\section{Renditta:-}

The silkworms reared on fortified mulberry leaves with folic acid at different concentrations expressed encouraging results in respect of renditta. The lowest renditta of 9.49 and $9.51 \mathrm{~kg}$ were recorded in Hosa Mysore and MU1, respectively. The improvement for this trait in both multivoltine breeds at $0.6 \%$ of folic acid supplementation might be due to effective utilization of this vitamin in transamination reaction in turn reflect on cocoon shell formation. These results are in agreement with the findings of Sridhar and Radha (1987) who noticed that silkworm reared on mulberry leaf supplemented with $10 \mathrm{ppm}$ concentration of glycine extracted significant reduction in renditta.

\section{Fecundity:-}

It is one of the fitness parameter. The multivoltine silkworm breeds Hosa Mysore and MU1 nourished with mulberry leaves fortified with folic acid at varied concentrations exerted marked influence on fecundity. A concentration of folic acid at $0.6 \%$ resulted in higher fecundity of 484 and 477 eggs in Hosa Mysore and MU1, respectively over larvae provided with natural diet. The increase in fecundity in both the breeds may be due to additional supplementation of folic acid with mulberry leaves. The current results conformity with those of Chauhan and Singh (1992) who reported that silkworm supplemented with folic acid at $1 \%$ concentration enhance fecundity. Similar trend was also observed with supplementation in the silkworm breed NB4D2 by Nirwani and Kaliwal (1998).

\section{Summary:-}

Both multivoltine breeds showed marked improvement on larval weight, cocoon weight, shell weight, filament length, filament weight, renditta except denier at $0.6 \%$ folic acid supplementation over other treated batches as well as control batches.

\section{References:-}

1. Babu, M; Swamy, M.T; Rao, P.K. and Rao, M.S. (1992) Effect of ascorbic acid enriched mulberry leaves on rearing of Bombyx mori L. Indian J. Seric., 31P: 111-114.

2. Babu, V.P. (1994) Influence of supplementation of L- glycine on parent silkworm, Bombyx mori L. And grainage, rearing and cocoon parameters during successive generation. M.Sc. thesis, UAS, Bangalore, pp. 122.

3. Balasundaram, D. P., Selvisabhanayakam, G.P., Mathivanan, V and Ramesh, V. (2013a) Biotechnological applications and nutritional supplementation of ascorbic acid (vitamin c) treated Morus alba L. Leaves fed by 
silkworm Bombyx mori (L.) (Lepidoptera:Bombycidae) in relation to silk production International Journal of Research in Biomedicine and Biotechnology, 3(1):11-162.

4. Balasundaram, D. P., Selvisabhanayakam, G.P., Mathivanan, V and Ramesh, V. (2013b) Studies on the nutritional supplementation of vitamin $\mathrm{c}$ treated MR2 mulberry leaves fed by $5^{\text {th }}$ instar larvae of silkworm Bombyx mori L. (Lepidoptera:Bombycidae) in relation to feed efficacy and growth rate. International Journal of Research in Biotechnology and Biochemistry. 3(1):11-18.

5. Chauhan, T. P. S. And Kamalaingh, (1992) Studies on the effect of ascorbic acid (vitamin-C) on the fecundity in the mulberry silkworm (Bombyx mori L.).Sericologia, 32(4):567-574.

6. Cui, W.Z.; Shang, J.Y; Wang,B. (2003) Effect of vitamin-C on feeding habit and growth and development of the silkworm, Bombyx mori L. Sericologia, 43(1):73-80.

7. Dadd,R.H. (1960) Some effect of dietary ascorbic acid on locusts. Proc. R.Soc.(B) $153: 128-143$.

8. Dadd,R.H.(1963) Feeding behavior and nutrition in grasshoppers and locust. Adv. Insect Physiology. 1:47-109.

9. Dobzhenok, N.V. (1974) The effect of ascorbic acid on the physiological condition of the codling moth and its resistance to fungus and bacterial infection. Zakhist Roslin. 19: 3-7.

10. El-Karaksy, I.A. and Idriss, M. (1990) Ascorbic acid enhances the silk yield of the mulberry silkworm, Bombyx mori L. Sericologia, 32; 567-574.

11. Erma. S., Vanzerdant., Marry C. Pool and C.D. Richardson (1962)The role of ascorbic acid in the nutrition of the three cotton insects. J. Insect Physiology.8: 287-297.

12. Felton, G.W. and Summers, C. B.(1993) Potential role of ascorbic oxidase as a plant defense protein against insect herbivory. J. Chem. Ecol. 19: 1553-1568.

13. Gamo, T. (1941) on the variation of the content of ascorbic acid during development and metamorphosis of the silkworm Bombyx mori L. Uyeda. Bull. Seric. Ind. 13: 63-69.

14. Horie.Y., K. Watanabe and T.Ito (1966) Nutrition of the Bombyx mori. XIV. Further studies on the requirement for B vitamins. Bull. Sericult. Exp. Stan.Japan 20:393-409.

15. Ito,T.(1978)Silkworm nutrition In: The silkworm; An important laboratory Tool. (Ed Tazima, Y). Tokyo Kodansha Ltd. Pp, 307.

16. Kaur, S and B.G.Srivastava (1995) Effect of ascorbic acid its different quantities on various parameters of reproductive potential of Dacus cucurbitae. Ind. J. Entomol 57(2):151-156.

17. Legay, J.M. (1958) Recent advances in Silkworm nutrition. Ann. Rev.Entomol.3:75-86.

18. Nirwani, R.B and B.B. Kaliwal (1995) Effect of folic acid on e conomic traits, glycogen and protein contents of the fat body and trehalose and protein content of the haemolymph of the silkworm, Bombyx mori. L Korean J.Seric.Sci.38(2):118-123.

19. Nirwani, R.B and B.B. Kaliwal.(1998)Effect of thiamine on commercial traits and biochemical contents of the fat body and haemolymph in the silkworm, Bombyx mori L. Sericologia. 38:639-646.

20. Pant, N.C. (1978) Insect nutrition in economic entomology. In : Insect Physiology and Anatomy (Eds. N.C. Pant and S. Ghai). ICAR, New Delhi, pp.209-212.

21. Prasad,P. R; Urs, K.C.D. and Govindan, R. (1994) Effect of fortification of ascorbic acid through mulberry leaf on cocoon traits of Pure Mysore, $\mathrm{NB}_{4} \mathrm{D}_{2}$ and $\mathrm{PM} \times \mathrm{NB}_{4} \mathrm{D}_{2}$ races of silkworms, Bombyx mori L. Scond Natl. Symp. Prosp. Prob. Seric., India (March, 7-9), Madras Univ., Vellore, pp: 137.

22. Rahmathulla, V.K., H.M.Suresh, V.B. Mathur, and R.G.Geethadevi,(2002) feed conversion efficiency of elite bivoltine CSR hybrids silkworm Bombyx mori L. reared under different environmental condition. Sericologia. 42(2): 297-203.

23. Rahmathulla, V.K., Priyabrata Das, M. Ramesh and Rajan, R.K.(2007) Growth rate pattern and economic traits of silkworm, Bombyx mori L under the influence of folic acid administration. J. Appl. sci. environ. manage., 11(4):81-84

24. Rai, M.M; Rathod, M.K. and Khurad, M.A.(2002) Improvement in economic characters of silkworm, Bombyx mori L. by folic acid administration. Entomon, 27(1):99-104.

25. Saiful Islam Furuki, (2005) Effect of pyridoxine on the reproduction of the mulberry silkworm, Bombyx mori L. (Lepidoptera: Bombycidae) Indian J. Seric.,2: 28-31.

26. Singaravelu, G; Sudha, D; Jayanthi, R; Porselvi, M.A. and Kalaivani, C.(2001) Biological role of vitamins on economic characters and some enzymatic activities in haemolymph of silkworm Bombyx mori L. Proc. Natl. Mulb. Seri. Re, India pp. 474-481.

27. Sridhar, P. and Radha, N.V.1987. Effect of supplementing glycine to the feed of silkworm Bombyx mori L. Proc. Seric. Symp. Semi., Coimbatore, pp.88-98.

28. Tantry, A.K. and Kanika Trivedy (2011) Significance of application time for dietary vitamin C supplementation in the silk silkworm Bombyx mori L. current Biotica,4(4 